\title{
THE DEVELOPMENT OF ENGLISH FOR TRANSPORTATION (ENTRA) APPLICATION FOR STUDENTS IN TRAINING AND EDUCATION PROGRAM FOR HUMAN RESOURCE DEVELOPMENT ON TRANSPORTATION AGENCY
}

\author{
Munawwir Hadiwijaya \\ IKIP Budi Utomo Malang \\ munawirhadiwijaya@budiutomomalang.ac.id \\ Ima Widiyanah \\ IKIP Budi Utomo Malang \\ Maya Rizki Amaliyasari \\ IKIP Budi Utomo Malang
}

\begin{abstract}
This research seeks to develop an English for Transportation (EnTra) application that can help cadets to master English transportation more easily. The design of this research is the ADDIE model development research. The following steps describe the research and development. (1). Conduct a needs analysis through preliminary research activities. (2). Planning in the form of product and participant determination. (3). The product to be developed is the English for Transportation (EnTra) application. (4). Expert validation in the form of expert / practitioner ratings of the Entra application includes format, language, illustrations and content, as well as multimedia experts, because the product produced is an android application. (5). Implementation of the product to the real target. (6) Product evaluation. The results of this study indicate that, there are seven aspects of assessment given by media expert, material expert and cadets as the aplication's users. The results of the assessment of the three parties indicate that the application developed has been tested and categorized as very feasible. This means that EnTra's idea of bringing class into one single application that can be accessed anywhere and at any time brings a different atmosphere for cadets in learning English transportation. The limited time they have in learning is overcome by this application.
\end{abstract}

Keywords: English for Transportation (Entra), ESP Transportation, Learning Media

\section{LATAR BELAKANG}

Pengimplementasian mata kuliah ESP (English for Specific Purposes) di perguruan tinggi negeri bidang transportasi pada dasarnya merupakan usaha menjawab tantangan terhadap dunia kerja dan kebutuhan stake holders. Masuknya Indonesia sebagai salah satu anggota MEA (Masyarakat Ekonomi Asia), menuntut para praktisi pendidikan agar mampu menghasilkan lulusan yang mampu bersaing secara global. Sekarang ini, Bahasa Inggris menjadi syarat mutlak untuk mecari pekerjaan. Pada saat interview pekerjaan di bidang trasnportasi, misalnya, sudah mensyaratkan TOEFL sebagai salah satu prasarat untuk bisa dijadikan pertimbangan untuk diterima. Hal ini terjadi karena perusahaan-perusahaan dibidang transportasi telah mempersiapkan mereka untuk lebih mampu berkompetisi secara global, terutama di era free trade saat ini dan diharapkan dengan menguasai Bahasa Inggris pasif maupun aktif mereka bisa melayani konsumen secara optimal baik lokal maupun internasional. Oleh karenanya, Bahasa Inggris sangatlah penting untuk dikuasai oleh taruna. 
Sebagai suatu pendekatan baru dalam pembelajaran Bahasa Inggris, ESP memiliki ciri dan karakteristik yang berbeda dengan pembelajaran Bahasa Inggris umum (General English). Karakteristik ini tentu juga berbeda secara jelas dan significant dengan pembelajaran Bahasa Inggris yang lain, seperti English as Second Language (ESL) atau English as A foreign Language (EFL). Hutchinson dkk. (1987) menyatakan bahwa ada empat karakteristik utama ESP sebagai pendekatan dalam pembelajaran Bahasa Inggris yaitu: (a) ESP dirancang untuk memenuhi kebutuhan pembelajar, (b) substansi dan isi ESP dikaitkan dengan tema dan topik pada bidang ilmu tertentu, (c) berpusat pada bentuk kebahasaan yang sesuai dengan aktivitas dan bidang ilmu atau pekerjaan yang dimiliki, (d) ESP berbeda dengan General English (GE).

Robinson (1990) selanjutnya menyatakan bahwa ada tiga ciri utama ESP yang membedakan dengan General English (GE), English as a Foreign Language (EFL), English as a Second Language (ESL). Ketiga karakteristik tersebut adalah berorientasi pada tujuan (Good Oriented). Dalam konteks ini pembelajar Bahasa Inggris bukan karena alasan ingin sekedar mengetahui bahasa sebagai bahasa dan budaya yang terkandung di dalamnya, akan tetapi pembelajar ESP memiliki tujuan khusus tertentu dan spesifik dalam bidang akademik dan profesi satu dengan lainya. Substansi ESP juga dirancang dan dikembangakan berdasarkan konsep analisis kebutuhan (need analysis). Konsep analisis kebutuhan bertujuan untuk mengkhususkan dan mengaitkan serta mendekatkan apa yang dibutuhkan pembelajar baik dalam bidang akademik maupun profesi. ESP pada dasarnya diajarkan pada tingkatan tinggi dan professional atau tempat kerja.

Akan tetapi, pembelajaran ESP di akademi/ kampus dalam lingkungan Lembaga Diklat Badan Pengembangan SDM Perhubungan masih belum efektif dan sesuai target yang diharapkan. Kurangnya ketertarikan taruna untuk belajar Bahasa Inggris secara lebih mendalam adalah masalah paling fundamental yang sering ditemui. Mereka mempelajari Bahasa Inggris hanya sebatas menggugurkan kewajiban saja karena Bahasa Inggris merupakan mata kuliah yang sifatnya wajib. Secara terperinci, berdasarkan analisa kebutuhan awal melalui observasi dan wawancara di Akademi/kampus di lingkungan Kementrian Perhubungan, yaitu: Akademi Perkeretaapian Indonesia Madiun, didapatkan gambaran tentang beberapa hambatan, baik yang dihadapi oleh para dosen ESP maupun para taruna, di antaranya sebagai berikut: (1) Kurangnya motivasi belajar bahasa Inggris ESP; (2)Media pembelajaran yang kurang menarik; (3) Tidak tersedianya bahan ajar yang sesuai dengan kebutuhan mereka; (4) Kosakata bahasa Inggris yang masih minim, membuat taruna kesulitan mempelajari serta menguasai ESP transportasi; (5) Tidak adanya acuan kurikulum yang yang jelas untuk dijadikan pedoman dalam pengajaran ESP.

Salah satu usaha dalam meningkatkan motivasi belajar taruna adalah melalui media pembelajaran yang menarik. Media pembelajaran menurut Daryanto (1993:1) adalah alat yang dapat membantu proses belajar mengajar yang berfungsi memperjelas makna pesan yang disampaikan sehingga tujuan pengajaran dapat disampaikan dengan lebih baik dan lebih sempurna. Menurut Thorn (dalam Munir 2009: 219-220) selama ini model dan media pembelajaran yang digunakan bersifat monoton dan konvensional, xssproses pembelajaran yang tidak efektif ini dapat ditanggulangi dengan menggunakan model dan media pembelajaran interaktif. Saat sekarang ada bermacam model dan media pembelajaran interaktif yang 
digunakan untuk menunjang proses pembelajaran misalnya CD tutorial pembelajaran, game edukasi dan masíh banyak lagi.

Media pembelajaran menurut Daryanto (1993) adalah alat yang dapat membantu proses belajar mengajar yang berfungsi memperjelas makna pesan yang disampaikan sehingga tujuan pengajaran dapat disampaikan dengan lebih baik dan lebih sempurna. Menurut Thorn (dalam Munir, 2009) selama ini model dan media pembelajaran yang digunakan bersifat monoton dan konvensional, proses pembelajaran yang tidak efektif ini dapat ditanggulangi dengan menggunakan model dan media pembelajaran interaktif. Saat sekarang ada bermacam model dan media pembelajaran interaktif yang digunakan untuk menunjang proses pembelajaran misalnya CD tutorial pembelajaran, game edukasi dan masíh banyak lagi.

Brown (1973) mengungkapkan bahwa media pembelajaran yang digunakan dalam kegiatan pembelajaran dapat mempengaruhi terhadap efektivitas pembelajaran. Pada mulanya, media pembelajaran hanya berfungsi sebagai alat bantu guru untuk mengajar yang digunakan adalah alat bantu visual. Sekitar pertengahan abad Ke -20 usaha pemanfaatan visual dilengkapi dengan digunakannya alat audio, sehingga lahirlah alat bantu audio-visual. Sejalan dengan perkembangan ilmu pengetahuan dan teknologi (IPTEK), khususnya dalam bidang pendidikan, saat ini penggunaan alat bantu atau media pembelajaran menjadi semakin luas dan interaktif, seperti adanya komputer dan internet.

Penelitian ini mencoba mengembangkan media pembelajaran berupa aplikasi Android yang berfokus pada ESP transportasi dengan menitikberatkan pada menguasaan kosa kata trasportasi menggunakan software MIT App Inventor. App Inventor adalah lingkungan pengembangan terintegrasi aplikasi web yang awalnya disediakan oleh Google, dan sekarang dikelola oleh Massachusetts Institute of Technology (MIT). Hal ini memungkinkan pendatang baru untuk pemrograman komputer untuk membuat perangkat lunak aplikasi (aplikasi) untuk dua sistem operasi (OS): Android, dan iOS, yang, pada 8 Juli 2019, sedang dalam pengujian beta final, dijadwalkan akan dirilis secara publik di musim panas 2019. Ini adalah perangkat lunak bebas dan sumber terbuka yang dirilis dengan lisensi ganda: lisensi Creative Commons Attribution ShareAlike 3.0 Unported, dan Apache License 2.0 untuk kode sumber (Hardesty, 2010).

Adapun spesifikasi dari media pembelajaran EnTra adalah sebagai berikut:

a) EnTra adalah media pembelajaran yang dikembangkan untuk membantu para taruna di perguruan tinggi bidang transportasi untuk dapat menguasai bahasa Inggris transportasi dengan lebih mudah.

b) EnTra merupakan digitalisasi dari materi-materi yang selama ini telah diajarkan pada para taruna dengan menambahkan dan mengurangi di beberapa bagian dengan berfokus pada kosa kata dalam transportasi dengan visualisasi berupa gambar, dengan dilengkapi arti, cara pengucapan, serta contoh penggunaan dalam konteks.

c) Secara teknis EnTra adalah aplikasi pembelajaran dalam bidang transportasi dalam bentuk aplikasi Android, yang diharapkan memudahkan taruna untuk belajar bahasa Inggris ESP transportasi. 


\section{METODE}

\section{Prosedur Pengembangan}

Dalam peneltian ini, model peneltian diadaptasi dari sepuluh prosedur peneltian dan pengembangan Borg and Gall (1983). Ada enam prosedur yang diaplikasikan dalam peneltian.

Berikut ini dipaparkan langkah-langkah penelitian dan pengembangan. (1). Melakukan analisis kebutuhan melalui kegiatan peneltian pendahuluan. (2). Melakukan perencanaan yang berupa penetapan produk dan partisipan. (3). Produk yang akan dikembangkan adalah media pembelajaran berupa aplikasi English for Transportation (EnTra) yang dapat membantu para taruna untuk dapat menguasai bahasa inggris transportasi dengan lebih mudah. (4). Validasi ahli berupa penilaian para ahli/praktisi terhadap media pembelajaran EnTra mencakup format, bahasa, ilustrasi dan isi. (5). Pengemasan merupakan tahap akhir. (6). Pengimplementasian produk kepada sasaran yang sesungguhnya.

Penelitian Pendahuluan

Tahap awal dalam penelitian dan pengembangan menggunakan model R\&D adalah melakukan penelitian pendahuluan. Dalam tahap ini, dilakukan analisis kebutuhan. Melalui analisis kebutuhan akan diidentifikasi permasalahan-permasalahan yang dijumpai dalam pembelajaran. Analisis kebutuhan inilah yang nantinya dijadikan acuan pengembangan produk. Berikut dipaparkan pelaksanaan penelitian pendahuluan dan analisis kebutuhan.

\section{Perencanaan}

Tahap kedua dalam R\&D adalah perencanaan yang meliputi penetapan spesifikasi produk dan penetapan partisipan.Berikut ini dipaparkan spesifikasi produk dan partisipan.

Penetapan Partisipan

Partisipan dalam pengembangan materi pembelajaran ini adalah (1) tim ahli, (2) dosen, (3) taruna.

\section{(1) Tim Ahli}

Tim ahli berperan memberi saran kritik dan penilaian terhadap produk yang dikembangkan mulai tahap perencanaan sampai dengan pengemasan. Untuk urusan isi, seorang ahli dalam penelitian ini adalah ahli media pembelajaran. Untuk spesifikasi aplikasi dibutuhkan ahli multimedia.

\section{(2) Dosen}

Dosen dalam hal ini merupakan partisipan yang terlibat dalam proses pembuatan produk serta memberikan saran maupun kritik terhadap produk yang dikembangkan. Dosen yang dilibatkan dalam penelitian ini dosen Bahasa Inggris ESP transportasi. 


\section{(3) Taruna}

Taruna dalam penelitian ini adalah calon pengguna produk, yaitu taruna Akademi Perkeretaapian Indonesia Madiun.

Penyusunan Model Pembelajaran yang Dikembangkan

Produk dikembangkan dengan mengacu pada tujuan yang ingin dicapai dalam penelitian. Tujuan yang ingin dicapai penelitian dijabarkan menjadi tiga, yaitu: (1) mengembangkan media pembelajaran berupa aplikasi English for Transportation (EnTra) yang dapat membantu para taruna untuk dapat menguasai bahasa inggris transportasi dengan lebih mudah, (2) mengembangkan materi ESP transportasi khususnya yang berkaitan dengan kosa kata seputar transportasi, dan (3) mengembangkan media pembelajaran berupa kamus khusus dalam bidang transportasi dalam bentuk aplikasi Android, yang diharapkan memudahkan taruna untuk belajar bahasa Inggris ESP transportasi.

\section{Validasi Ahli}

Penilaian dari tim atau dosen ahli untuk diberikan tanggapan berupa komentar, kritik, saran, dan penilaian yang terkait dengan kelayakan produk. Alat yang digunakan sebagai panduan penilaian uji kelayakan produk adalah isntrumen penilaian. Dalam instrumen, terdapat penilaian terhadap isi materi, ragam bahasa, dan grafika produk yang dikembangkan. Tanggapan dan penilaian tim ahli tersebut dijadikan dasar untuk melakukan revisi terhadap produk yang dikembangkan tersebut.

\section{Uji Coba Produk}

Pada tahap terakhir ini, produk yang sudah dikembangkan kemudian diujicobakan. Uji coba produk akan diuji dalam penelitian eksperimen. Uji coba ini bertujuan untuk mengetahui efektifitas produk dalam pengajaran Bahasa Inggris Umum (ESP transportasi).

\section{Instrument Penelitian}

Dalam penelitian ini, digunakan beberapa instrumen guna mencapai keberhasilan penelitian. Untuk analisis kebutuhan, penelitian ini menggunakan angket. Lembar observasi untuk proses pengamatan uji coba produk dan wawancara setelah pengaplikasian produk. Sedangkan rubrik penilaian untuk difungsikan untuk membantu tim ahli memberikan penilaian, saran dan masukan terhadap produk yang dikembangkan.

Data Analisis

Pada tahap ini, data yang sudah terekam melalui angket, pengamatan dan rubrik penilaian kemudian akan dianalisa secara kualitatif. Adapun hasil dari uji coba produk akan dianalisa dengan menggunakan statistik, yakni mengukur efektifitas produk. 


\section{HASIL DAN LUARAN YANG DICAPAI}

Pengembangan Produk

Tahap pembuatan media merupakan tahap realisasi dari perancangan flowchart dan storyboard, pada tahap ini media pembelajaran dibuat dengan menggunakan software MIT App Inventor dan Adobe Photoshop CS6.

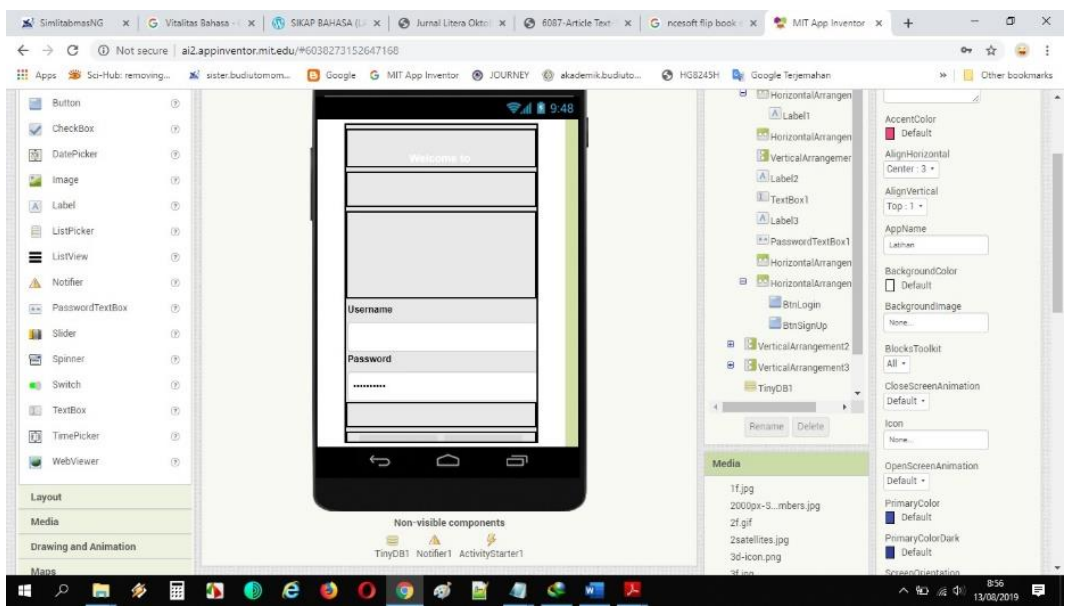

Gambar 1. Tampilan MIT App Inventor

Langkah-Langkah Pembuatan Aplikasi dengan menggunakan Software MIT App Inventor: Langkah awal yaitu dengan membuka lembar kerja MIT App Inventor dengan sign in akun Google; buka di browser alamat MIT App Inventor, http://ai2.appinventor.mit.edu; pilih project pada menu main bar bagian atas, pilih start new project. Keunggulan MIT App Inventor dibandingkan dengan aplikasi pengembang lainnya adalah, Bahasa pemrograman yang digunakan. Jika aplikasi lain menggunakan Bahasa Phyton atau Java Script, aplikasi ini menggunakan Block logika yang sangat memudahkan mereka yang tidak mengerti Bahasa coding.

Tahap selanjutnya mendisain aplikasi sesuai dengan konsep perancanagan yang telah dibuat sebelumnya pada lembar kerja yang telah dibuat, perguanaan tools-tools yang ada dipaling kanan untuk mendesain aplikasi., aplikasi dibuat dengan masing-masing bagian frame sesuai konten agar lebih memudahkan pengerjaan.

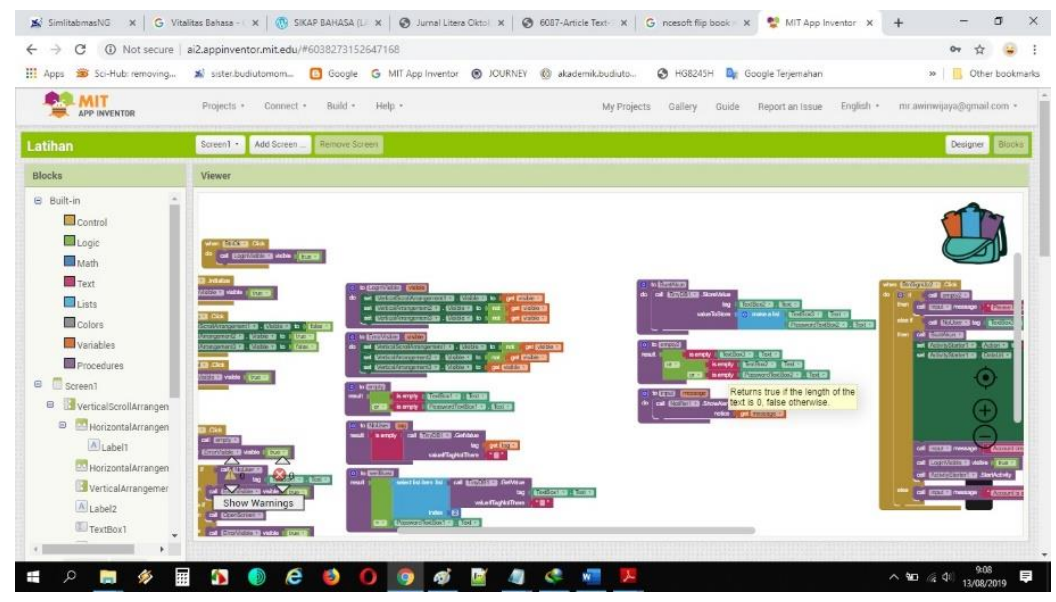

Gambar 2 Block logika dalam MIT App Inventor 
Pada setiap frame/ screen yang terdapat konten kita harus menambahkan Command Blocks yang berfungsi sebagai program di dalam aplikasi yang akan dibuat. Emulator digunakan untuk menjalankan block yang sudah diinput. Terdapat tiga pilihan emulator yang bisa digunakan: menggunakan AI Companion, caranya dengan mendownload aplikasi MIT AI Companion di Google Playstore pada Smartphone. Setelah terinstall jalankan aplikasi tersebut. Klik menu connect, AI Companion pada MIT App Inventor. Akan muncul barcode yang dapat scan oleh MIT AI Companion maka otomatis aplikasi yang baru dibuat terkoneksi dengan Smartphone.

Di samping cara di atas, Software MIT AI Inventor juga memiliki simulator bawaan, yaitu MIT AI Starter. tidak disarankan jika laptop yang digunakan memiliki spesifikasi standart, menggunakan emulator bawaan ini, karena akan sedikit berat ketika dijalankan.

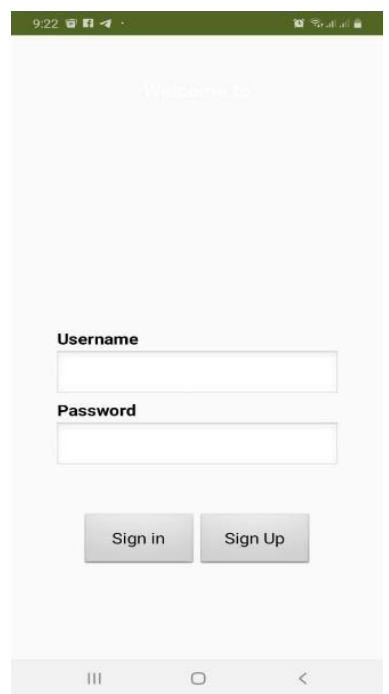

Gambar 3 menunjukan tampilan MIT Inventor yang telah terkoneksi dengan Smartphone

Setelah semua proses pembuatan aplikasi telah selesai dibuat maka lakukanlah proses simulasi yaitu untuk menguji apakah aplikasi yang telah dibuat bekerja dengan baik dan sudah sesuai perancangan. Proses terakhir dalam pembuatan aplikasi dengan menggunakan software MIT App Inventor adalah yaitu dengan mengkonvert/mempublish ke dalam bentuk .apk yang nantinya dapat diinstal di smartphone Android. 


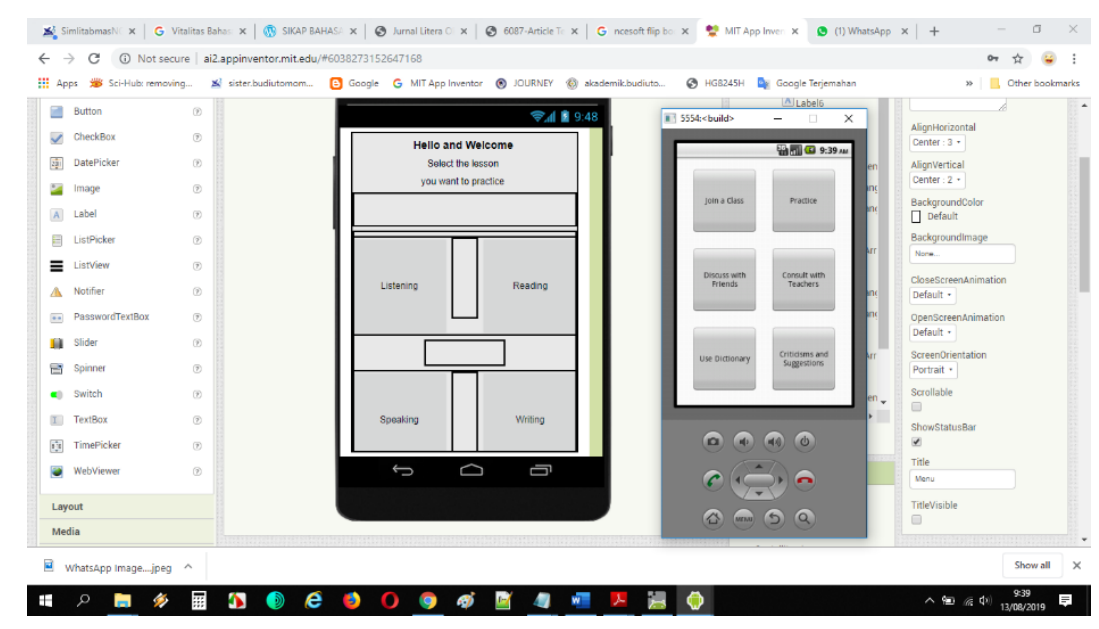

Gambar 4 menunjukan tampilan ketika melakukan simulasi.

Tahap pengujian pada smartphone dapat dijalan menggunakan proses debugging pada perangkat smartphone, pada penelitian ini tahap pengujian menggunakan smartphone Samsung Galaxy A30 dengan spesifikasi CPU: Octa-core $(2 \times 1.8 \mathrm{GHz}$ Cortex-A73 \& 6×1.6 GHz CortexA53), Android 9.0 (Pie), 4 GB RAM. Pengujian dilakukan untuk mengetahui apakah fungsifungsi yang terdapat dalam aplikasi setelah proses blocking dapat berjalan dengan benar dan untuk menemukan kekurangan atau kesalahan yang harus diperbaiki.

\section{Hasil Penelitian}

Pada penelitian ini peneliti melakukan tahapan, yaitu melakukan pengambilan data menggunakan kuesioner (Angket).

Terdapat tujuh aspek yang menjadi aspek penilaian baik ahli maupun taruna, yaitu: Aspek tampilan visual, Aspek relevansi media, Aspek pengorganisasian materi, Aspek rekayasa perangkat lunak, Aspek efek bagi strategi pembelajaran, Aspek bahasa, dan Aspek evaluasi.

\section{Aspek Tampilan Visual}

Aspek tampilan visual mengacu pada bagaimana hal-hal terlihat pada sistem visual. Objek memiliki sifat fisik, dan dalam hal ini, sifat optik biasanya paling relevan bersama dengan ukuran, tekstur, bentuk, dll. Caivano (2015). Aplikasi EnTra dibangun dengan menggunakan MIT App Inventor, penampilannya sedikit monoton karena tidak memiliki pilihan template. Namun, hasil validasi ahli media dan kuesioner dan wawancara yang dilakukan pada taruna program ESP Akademi Kereta Api Indonesia Madiun, selaku pengguna, melampaui apa yang diharapkan.

\section{Aspek Relevansi Media}

Media harus digunakan secara bijaksana dalam proses pembelajaran. Media dapat digunakan untuk memotivasi diskusi atau menjelaskan suatu konsep. EnTra menggunakan beberapa media dalam menyampaikan materi pembelajaran. 1) Video, video yang dipilih, berasal dari situs sumber terbuka, seperti YouTube, metube, dll., Yang relevan dengan topik yang sedang 
dibahas, digunakan untuk memudahkan taruna memahami materi yang sedang dibahas; 2) Gambar, seperti sketsa, kartun, dan gambar lain yang relevan juga terintegrasi dalam aplikasi; 3) dan Audio, yang sebagian besar digunakan dalam sesi Mendengarkan.

Aspek Pengorganisasian Materi

Aspek pengorganisasian materi mengacu pada pendekatan sistematis untuk menyimpan dan mengambil bahan. Organisasi spesifik tergantung pada pengaturan dan ruang di kelas dan pada gaya dan preferensi guru dan siswa yang bekerja di ruangan itu. Tujuan dari pengorganisasian materi adalah untuk memberikan siswa dan guru akses cepat ke materi yang benar dengan jumlah minimum gangguan belajar (Robinson, 1990). Dengan kata sederhana, hal ini merujuk pada bagaimana materi ESP tentang transportasi disajikan dalam Aplikasi EnTra.

Ide EnTra adalah untuk membawa kelas menjadi satu aplikasi tunggal yang dapat diakses di mana saja dan kapan saja. Ada enam fitur utama dalam aplikasi ini, yaitu: Bergabung dengan fitur kelas, fitur latihan, berdiskusi dengan fitur teman, berkonsultasi dengan fitur guru, menggunakan fitur kamus, dan fitur kritik dan saran. Para taruna dapat memilih fitur berdasarkan kebutuhan mereka dalam belajar. Setiap pelajaran dilengkapi dengan latihan untuk mengukur pemahaman taruna tentang pelajaran yang dipelajari. Para taruna juga dapat mengikuti diskusi tentang pelajaran yang didiskusikan dengan fitur teman. Jika mereka mengalami beberapa kesulitan, taruna dapat berkonsultasi dengan guru secara pribadi dengan memilih berkonsultasi dengan fitur guru, di mana secara langsung terhubung ke nomor telepon guru melalui WhatsApp. EnTra juga dilengkapi dengan kamus sederhana dalam transportasi, setiap kali taruna menghadapi kesulitan dalam beberapa hal, mereka dapat menggunakan fitur ini. Yang terakhir adalah fitur kritik dan saran, fitur ini dibuat untuk mengundang pengguna/ taruna untuk memberikan kritik atau saran mereka untuk peningkatan aplikasi.

\section{Aspek Rekayasa Perangkat Lunak}

Aspek rekayasa perangkat lunak mengacu pada proses menganalisis kebutuhan pengguna dan merancang, membangun, dan menguji aplikasi pengguna akhir yang akan memenuhi kebutuhan ini melalui penggunaan bahasa pemrograman perangkat lunak. Ini adalah penerapan prinsip-prinsip teknik untuk pengembangan perangkat lunak. Berbeda dengan pemrograman sederhana, rekayasa perangkat lunak digunakan untuk sistem perangkat lunak yang lebih besar dan lebih kompleks, yang digunakan sebagai sistem kritis untuk bisnis dan organisasi (Hardesty, 2010).

Seperti dijelaskan sebelumnya bahwa aplikasi dibangun dengan menggunakan perangkat lunak open source yang disebut MIT App Inventor, di mana dibandingkan dengan pembangun Android serupa lainnya, itu lebih sederhana dan lebih monoton dalam penampilan visual. Ini menggunakan antarmuka pengguna grafis (GUI) yang sangat mirip dengan bahasa pemrograman Scratch dan antarmuka pengguna StarLogo TNG, yang memungkinkan pengguna untuk menarik dan melepaskan objek visual untuk membuat aplikasi yang dapat berjalan pada perangkat seluler. Dalam menciptakan App Inventor, Google memanfaatkan penelitian penting sebelumnya dalam komputasi pendidikan, dan pekerjaan yang dilakukan dalam Google dalam lingkungan pengembangan online. 
Aspek Efek bagi Strategi Pembelajaran

Aspek efek bagi strategi pembelajaran mengacu pada metode yang digunakan taruna untuk belajar. Strategi pembelajaran adalah pendekatan individu untuk menyelesaikan tugas. Lebih khusus lagi, strategi pembelajaran adalah cara individu mengatur dan menggunakan seperangkat keterampilan tertentu untuk mempelajari konten atau menyelesaikan tugas-tugas lain secara lebih efektif dan efisien di sekolah serta di lingkungan nonakademik (Schumaker \& Deshler, 1992). Oleh karena itu, guru yang mengajarkan strategi belajar mengajar taruna cara belajar, daripada mengajar mereka konten kurikulum khusus atau keterampilan khusus.

Sekali lagi, ide EnTra adalah untuk membawa kelas ke dalam satu aplikasi tunggal yang dapat diakses di mana saja dan kapan saja membawa suasana yang berbeda kepada taruna dalam belajar bahasa Inggris. Keterbatasan waktu yang mereka miliki dalam pembelajaran diatasi dengan aplikasi ini.

Aspek Bahasa (Linguistik)

Newmonic (2016) menyatakan bahwa ada tiga aspek utama linguistik: bentuk, konten, dan penggunaan. Bentuk: termasuk blok bangunan bahasa seperti morfologi (tata bahasa), sintaksis (kalimat) dan kesadaran fonologis (kesadaran suara). Konten: mencakup faktor-faktor seperti semantik, termasuk pengetahuan kata (word knowledge) dan pengetahuan dunia (World knowledge), dan kosa kata. Penggunaan: area pragmatik. Artinya, pemahaman dan penggunaan bahasa dalam konteks sosial. Ini termasuk kemampuan untuk menggunakan bahasa yang tepat dalam lingkungan komunikatif dan sosial, dan memahami aturan sosial.

Dalam aplikasi ini, bahan yang digunakan dikompilasi dari banyak buku transportasi ESP. Materi tersebut dipilih dan disusun berdasarkan hasil analisis kebutuhan pada taruna yang mengikuti program ESP Akademi Kereta Api Indonesia Madiun sebelum aplikasi dikembangkan. Ada tiga masalah utama yang dihadapi oleh taruna dalam program ESP: 1) taruna membutuhkan lebih banyak media dalam pembelajaran; 2) mereka kehilangan antusiasme karena strategi pembelajaran yang digunakan oleh guru sedikit membosankan; 3) mereka tidak memiliki waktu yang cukup untuk belajar bahasa Inggris, karena kesempatan mereka untuk belajar hanya di kelas, yang hanya 100 menit seminggu.

\section{Aspek Evaluasi/ Latihan Soal}

Evaluasi adalah penentuan sistematis atas nilai, kepatutan, dan signifikansi subjek, dengan menggunakan kriteria yang diatur oleh serangkaian standar (Jones, 1990). Dalam mengecek pemahaman taruna, aplikasi ini menggunakan banyak latihan soal yang muncul atau dapat dipilih setelah taruna menyelesaikan materi pelajaran. Beberapa jenis gaya pertanyaan digunakan sebagai variasi tes untuk menghindari kebosanan, seperti pilihan ganda, pertanyaan WH, mencocokkan, penarikan kesimpulan, dll. Setiap sesi latihan dilengkapi dengan sistem penilaian yang muncul setelah item terakhir terjawab. Para taruna tidak dapat kembali ke item sebelumnya karena langsung menghilang setelah dijawab. Hal ini berguna untuk menjaga sikap "fair" taruna dan mengukur pemahaman mereka yang sebenarnya. Dengan menerapkan model evaluasi semacam ini, para taruna diarahkan untuk mempersiapkan diri mereka untuk 
Volume 6 Nomor 1 Tahun 2019 eISSN : $25494155-$ pISSN $: 23557083$

menghadapi tes TOEFL atau sejenisnya, yang dapat mengukur kemampuan bahasa Inggris mereka.

Validasi Ahli Materi

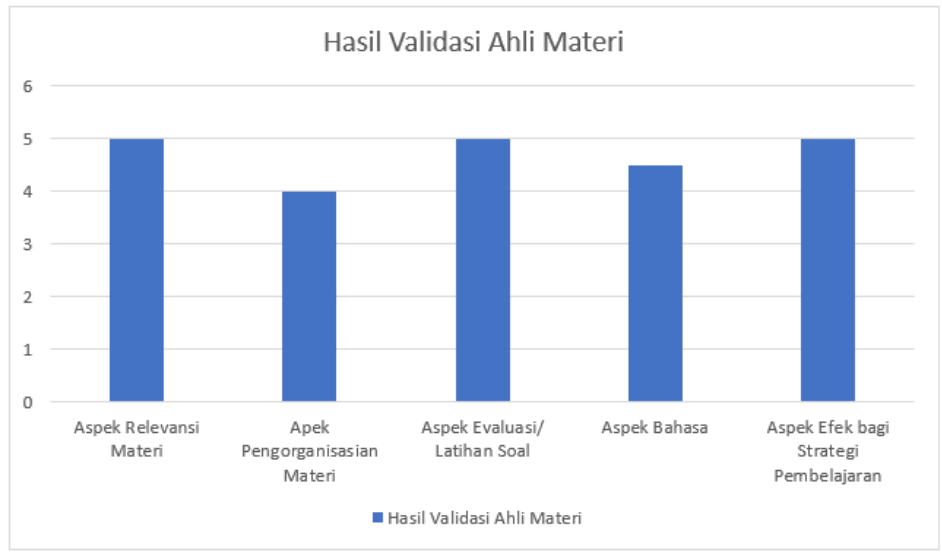

Gambar 6. Diagram batang hasil Validasi Ahli Materi

Berdasarkan Gambar 6 dapat disimpulkan bahwa penilaian media pembelajaran Aplikasi English for Transportation (EnTra) berdasarkan seluruh aspek penilaian materi mendapatkan nilai rata-rata 4.55 dengan presentase nlai $90.91 \%$ yang berada pada kategori Sangat Layak digunakan sebagai aplikasi belajar.

Validasi Ahli Media

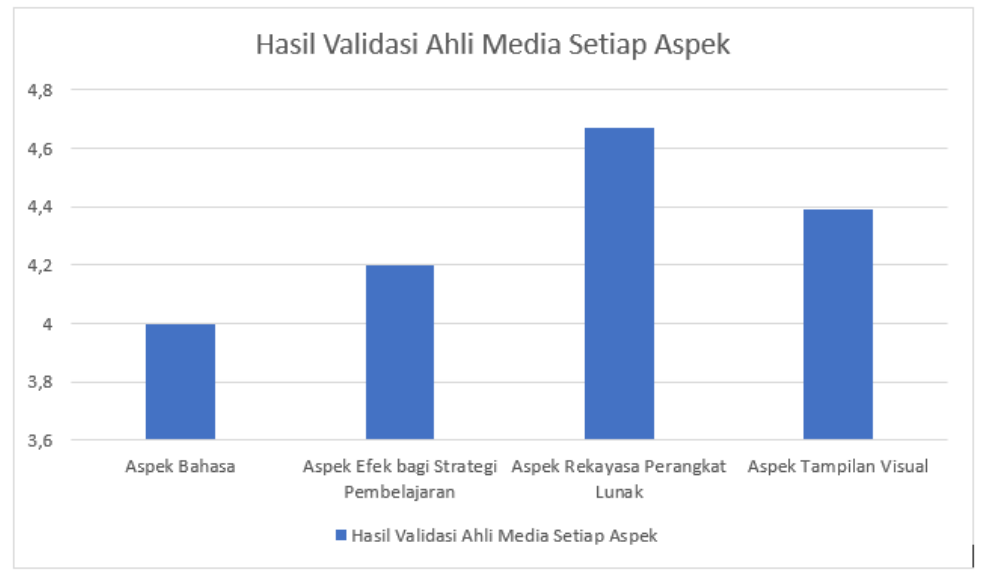

Gambar 7. Diagram batang hasil Validasi Ahli Media

Berdasarkan Gambar 7 dapat disimpulkan bahwa penilaian media pembelajaran Aplikasi English for Transportation (EnTra) berdasarkan seluruh aspek penilaian media mendapatkan nilai rata-rata 4.31 dengan presentase nlai $86.25 \%$ yang berada pada kategori Sangat Layak digunakan sebagai aplikasi belajar. 
Penilaian Taruna

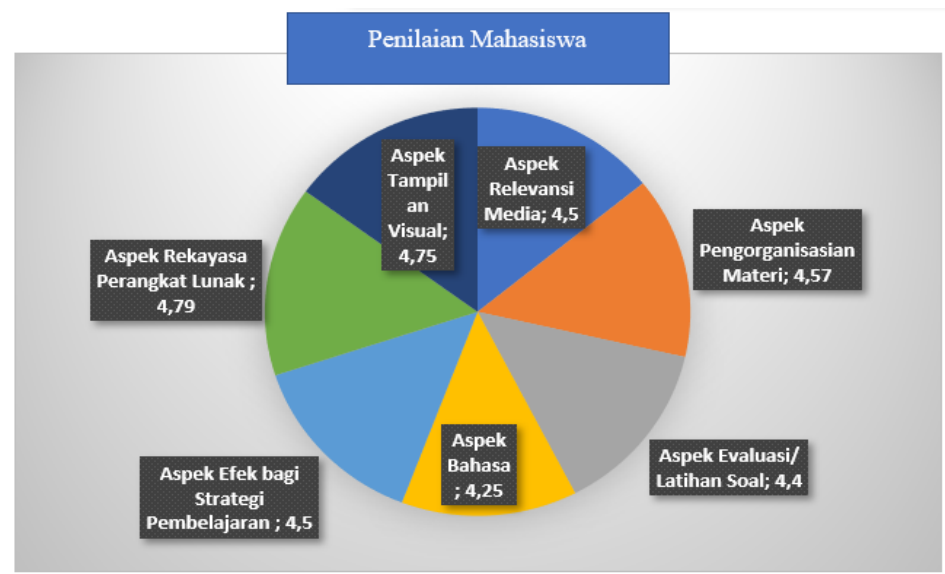

Gambar 8. Diagram hasil Penilaian Taruna

Berdasarkan Gambar 8 dapat diketahui bahwa rata-rata skor yang di dapatkan dari penilaian taruna terhadap media Aplikasi English for Transportation (EnTra) yaitu $(\mathrm{X})=4.03$ yang berdasarkan tabel rentang penilaian berada pada 3,41 - 4,20 yang dapat dikategorikan Layak, dari hasil perhitungan menunjukan bahwa dari kualitas aspek materi dan penggunaannya berdasarkan aspek relevansi materi, aspek pengorganisasian materi, aspek evaluasi/latihan soal, aspek bahasa, aspek efek bagi strategi pembelajaran, aspek rekayasa perangkat lunak, dan aspek tampilan visual, media Aplikasi English for Transportation (EnTra) yang telah dibuat layak digunakan sebagai multimedia pembelajaran interaktif oleh taruna.

\section{KESIMPULAN}

Adapun kesimpulan hasil dari analisis penelitian yang penulis lakukan adalah sebagai berikut: 1) Pengembangan Aplikasi English for Transportation (EnTra) telah dikembangkan dengan menggunakan model pengembangan ADDIE yaitu melalui proses analisis (Analysis), desain (Design), pengembangan (Development), Implementasi (Implementation), dan evaluasi (Evaluation). Pada penelitian ini dibatasi hanya sampai tahap implementasi. 2) Tingkat kelayakan aplikasi android dapat dilihat dari hasil validasi ahli materi, ahli media, dan penilaian taruna.

Penilaian kelayakan oleh ahli materi mendapatkan nilai rata-rata 4.55 dengan persentase $90.91 \%$ dan termaksud dalam kategori Sangat Layak. Penilaian kelayakan oleh ahli media mendapatkan nilai rata-rata 4.31 dengan persentase $86.26 \%$ dan termaksud dalam kategori Sangat Layak. Pada tahap implementasi kepada taruna mendapatkan nilai rata-rata 4.03 dengan persentase 80.53 dan termaksud dalam kategori layak. Hal ini menandakan bahwa aplikasi yang dikembangkan mampu menjawab permasalahan para taruna yang muncul dalam kelas ESP transportasi dan memenuhi kebutuhan taruna yang tergambar dalam proses analisa kebutuhan penelitian pengembangan ini. Ide EnTra yang membawa kelas ke dalam satu aplikasi tunggal yang dapat diakses di mana saja dan kapan saja membawa suasana yang berbeda bagi taruna dalam belajar bahasa Inggris transportasi. Keterbatasan waktu yang mereka miliki dalam pembelajaran diatasi dengan aplikasi ini. 
Akan tetapi, peneliti menyadari bahwa masih banyak aspek dari penelitian ini yang harus ditinjaklanjuti. Perancangan strategi pembelajaran dengan menggunakan aplikasi ini masih harus dirumuskan lebih lanjut. Dari segi implementasi, pengujian penggunaan aplikasi ini dalam kelas dalam rangka memecahkan masalah yang dihadapi oleh taruna secara ajeg dan berkesinambungan perlu untuk dilakukan, baik dengan menggunakan penelitian tindakan kelas ataupun penelitian eksperimental.

\section{DAFTAR RUJUKAN}

Borg and Gall (1983). Educational Research, An. Introduction. New York and London. Longman Inc

Brown, R. (1973). A first language: The early stages. Cambridge: Cambridge University Press.

Caivanoa, J.S. (2015). Appearance.Encyclopedia of Color Science and Technology. New York: Springer Science+Business Media.

Daryanto, (1993). Media Visual Pengajaran Teknik. Tarsito. Bandung

Hardesty, L. (2010). The MIT roots of Google's new software. MIT News Office.

Hutchinson, T., \& Waters. A. (1987). English for Specific Purposes: International in Scope, Specific in Purpose. TESOL Quarterly, 25:297-314

Jones. G. (1990). English for Specific Purposes. Cambridge: Cambridge University Press

Munir. (2009). Pembelajaran Jarak Jauh Berbasis Teknologi Informasi dan Komunikasi. Bandung: Alfabeta.

Newmonic. D. (2016). What is language?. [online], http://www.speechlanguageresources.com/What-is-language.html, accessed on 02 September 2019.

Putri N.,A. \& Yuniawan, T. (2017). Pengembangan Kamus Bergambar Berwawasan Cinta Indonesia Berbasis Aplikasi Android Sebagai Media Pembelajaran Bagi Mahasiswa Penutur Asing. Lingua, 8 (1) 60-67.

Robinson, P.C. (1990). ESP Today: A Practitioner's Guide. New York: Longman Phoenix Prentice Hall ELT.

Schumaker, J. B., \& Deshler, D. D. (1992). Validation of learning strategy interventions for students with LD: Results of a programmatic research effort. In Y. L. Wong (Ed.), Contemporary intervention research in learning disabilities: An international perspective. New York: Springer-Verlag. 